\title{
Effect of Preparation Method on Chemical Stability of Sinterable Calcium Doped Lanthanum Chromites
}

\author{
Natsuko SAKAI, Tatsuya KAWADA, Harumi YOKOKAWA and Masayuki DOKIYA \\ National Institute of Materials and Chemical Research, Tsukuba Research Center, 1-1, Higashi, Tsukuba-shi, Ibaraki
}

\author{
焼結性ランタンクロマイトの化学的安定性に及ぼす調製法の影響 \\ 酒井夏子・川田達也・横川晴美・土器屋正之 \\ 物質工学工業技術研究所, 305 茨城県つくば市東 1-1
}

[Received April 16, 1993; Accepted August 18, 1993]

\begin{abstract}
The effect of preparation method on the chemical stability of sinterable (La, Ca) $\mathrm{CrO}_{3-\delta}$ powder was investigated. The ceramic method (powder mixing method) resulted in inhomogeneous distributions of the calcium content $(x)$ in the perovskite phase $\left(\mathrm{La}_{1-x} \mathrm{Ca}_{x} \mathrm{CrO}_{3-\delta}\right)$ after calcining at a temperature from 1223 to $1373 \mathrm{~K}$. More homogeneous powder was obtained by the liquid mixing method. The distribution of calcium content caused a large amount of second phases such as calcium oxychromates $\left(\mathrm{Ca}_{m}\left(\mathrm{CrO}_{4}\right)_{n}\right)$ in a powder prepared by the ceramic method, and an excess amount of the second phase remained as $\mathrm{Ca}_{5}\left(\mathrm{CrO}_{4}\right)_{3} \mathrm{OH}$ on the surface of the ceramics after sintering at $1573 \mathrm{~K}$. During a treatment in an $\mathrm{H}_{2}+\mathrm{H}_{2} \mathrm{O}$ gaseous mixture at $1273 \mathrm{~K}$ for $627 \mathrm{~h}, \mathrm{Ca}_{m}\left(\mathrm{CrO}_{4}\right)_{n}$ decomposed to $\mathrm{CaO}$ and $\alpha-\mathrm{CaCr}_{2} \mathrm{O}_{4}$, and the decomposition was enhanced by the existence of silicon-containing impurities. The liquid mixing method minimized the amount of $\mathrm{Ca}_{m}\left(\mathrm{CrO}_{4}\right)_{n}$, and resulted in sufficient chemical stability in $\mathrm{H}_{2}+\mathrm{H}_{2} \mathrm{O}$.
\end{abstract}

Key-words : Lanthanum chromite, Preparation, Chemical stability, Inhomogeneity, Solid oxide fuel cell

\section{Introduction}

Calcium doped lanthanum chromite $\left(\mathrm{La}_{1-x} \mathrm{Ca}_{x}\right.$ $\mathrm{CrO}_{3-\delta}$ ) has a potential for use as an interconnect of solid oxide fuel cell (SOFC).1),2) Since $\mathrm{La}_{1-x} \mathrm{Ca}_{x}$ $\mathrm{CrO}_{3-\delta}$ powder has poor sinterability in air, many attempts have been made to obtain the dense, gas tight plates. ${ }^{1)-5)}$ We have suggested that a slight amount of nominal chromium deficiency (or A-site metal excess) is effective in improving the sinterability in air. ${ }^{6)-8)}$ Calcium oxychromates, $\mathrm{Ca}_{m}\left(\mathrm{CrO}_{4}\right)_{n}$, form as second phases to compensate the chromium deficiency at sintering temperatures (ca. $1573 \mathrm{~K}$ ). They exist as a liquid phase at above $1333 \mathrm{~K}$, and enhance the grain growth and joining of $\mathrm{La}_{1-x} \mathrm{Ca}_{x} \mathrm{CrO}_{3-\delta}$ particles. In this paper, this sinterable calcium doped lanthanum chromite is represented as $(\mathrm{La}, \mathrm{Ca}) \mathrm{CrO}_{3-\delta}$ to distinguish from pure perovskite phase, $\mathrm{La}_{1-x} \mathrm{Ca}_{x}$ $\mathrm{CrO}_{3-\delta}$. Second phases may remain at grain boundaries or on surfaces of the sintered sample even after completion of the sintering. ${ }^{8)}$ Hence, sintered (La, Ca) $\mathrm{CrO}_{3-\delta}$ can be considered as a composite of the perovskite phase $\left(\mathrm{La}_{1-x} \mathrm{Ca}_{x} \mathrm{CrO}_{3-\delta}\right)$ and a small amount of second phases such as $\mathrm{Ca}_{m}\left(\mathrm{CrO}_{4}\right)_{n}$.

Chemical stability of ( $\mathrm{La}, \mathrm{Ca}) \mathrm{CrO}_{3-\delta}$ should be investigated to utilize this material for the interconnect of SOFC which is placed in reducing atmospheres at high temperatures. Chemical stability of sintered $(\mathrm{La}, \mathrm{Ca}) \mathrm{CrO}_{3-\delta}$ may be greatly influenced by $\mathrm{Ca}_{m}\left(\mathrm{CrO}_{4}\right)_{n}$, since $\mathrm{Ca}_{m}\left(\mathrm{CrO}_{4}\right)_{n}$ have high valence states of chromium (IV-VI) which are no longer stable at high temperatures or in reducing atmospheres. Yasuda et al. have recently reported that sintered ( $\mathrm{La}, \mathrm{Ca}) \mathrm{CrO}_{3-\delta}$ exhibit serious degradation when it was placed in $\mathrm{H}_{2} \mathrm{O}+$ air, or $\mathrm{H}_{2}+\mathrm{H}_{2} \mathrm{O}$ $+\mathrm{N}_{2}$ at $1273 \mathrm{~K}:{ }^{9)} \mathrm{Ca}_{5}\left(\mathrm{CrO}_{4}\right)_{3} \mathrm{OH}$ was found on the surface after the sample was treated at $1273 \mathrm{~K}$ for $48 \mathrm{~h}$ in air with $30 \%$ moisture, and it entirely covered the perovskite phase $\left(\mathrm{La}_{1-x} \mathrm{Ca}_{x} \mathrm{CrO}_{3-\delta}\right)$. If such a second phase is precipitated on the interconnects in SOFC, it may cause the bad contacts with electrodes, and lower the cell efficiency. It is most likely that $\mathrm{Ca}_{5}\left(\mathrm{CrO}_{4}\right)_{3} \mathrm{OH}$ originates from the $\mathrm{Ca}_{m}$ $\left(\mathrm{CrO}_{4}\right)_{n}$ which exist in the sintered $(\mathrm{La}, \mathrm{Ca}) \mathrm{CrO}_{3-\delta}$. It seems that Yasuda's results are due to a large amount of second phases remaining in the sintered sample made by the ceramic method. The amounts and the distributions of second phases in sintered ( $\mathrm{La}, \mathrm{Ca}) \mathrm{CrO}_{3-\delta}$ may greatly depend on the preparation conditions such as calcining temperatures or mixing methods. From this viewpoint, it should be noted that the ceramic method is not desirable for the preparation of ( $\mathrm{La}, \mathrm{Ca}) \mathrm{CrO}_{3-\delta}$ because it may cause the formation of a large amount of second phases. To clarify this problem in detail, experimental investigation has been made. This paper reports the effects of preparation methods on the characteristics of $(\mathrm{La}, \mathrm{Ca}) \mathrm{CrO}_{3-\delta}$ powders, and on chemical stabilities of sintered ( $\mathrm{La}, \mathrm{Ca}) \mathrm{CrO}_{3-\delta}$ in reducing atmosphere $\left(\mathrm{H}_{2}+\mathrm{H}_{2} \mathrm{O}\right)$.

\section{Experimental}

\subsection{Sample preparation}

The molar ratio of metal components was set to La : $\mathrm{Ca}: \mathrm{Cr}=0.70: 0.32: 1.00$, this composition may give dense samples by low temperature sinter- 
ing at $1573 \mathrm{~K}$ in air. ${ }^{8)}$ Two preparation methods were adopted. In the ceramic method, appropriate amounts of $\mathrm{La}_{2} \mathrm{O}_{3}, \mathrm{CaCO}_{3}$ and $\mathrm{Cr}_{2} \mathrm{O}_{3}$ powders were mixed in an $\mathrm{Al}_{2} \mathrm{O}_{3}$ pot mill with $\mathrm{YSZ}$ (yttria stabilized zirconia) balls and ethanol for $48 \mathrm{~h}$. This mixture is called Sample 1. In the liquid mixing method, an appropriate mixture of aqueous solutions of $\mathrm{La}$ $\left(\mathrm{NO}_{3}\right)_{3}, \mathrm{Ca}\left(\mathrm{NO}_{3}\right)_{3}$ and $\mathrm{Cr}\left(\mathrm{NO}_{3}\right)_{3}$ was added to an excess amount of oxalic acid $\left(\mathrm{H}_{2} \mathrm{C}_{2} \mathrm{O}_{4}\right)$-ethanol solution. Although the lanthanum and the calcium were precipitated as oxalates, the chromium component formed soluble complexes with oxalic acid. This mixture is called Sample 2. Each mixture was heated on a hot plate to remove solvents, and pre-calcined at $623 \mathrm{~K}$ to remove residual organic compounds.

2.2 Investigation on the characteristics of calcined powders

Each pre-calcined powder was divided to several portions and calcined at different temperatures (823 K, $923 \mathrm{~K}, 1023 \mathrm{~K}, 1123 \mathrm{~K}, 1223 \mathrm{~K}$ and $1323 \mathrm{~K}$ for both samples, $1373 \mathrm{~K}$ and $1473 \mathrm{~K}$ for Sample 1) for $10 \mathrm{~h}$ in air. Each calcined powder was identified by powder X-ray diffraction (XRD, PW-1800, Philips
Co., Ltd., the Netherlands, $\left.\lambda=1.54056 \AA\left(\mathrm{Cu} \mathrm{K} \alpha_{1}\right)\right)$. Lattice constants of the perovskite phase $\left(\mathrm{La}_{1-x} \mathrm{Ca}_{x}\right.$ $\mathrm{CrO}_{3-\delta}$ ) were determined using silicon as a reference material. The powders calcined at $1273 \mathrm{~K}$ were investigated by scanning electron microscope and energy dispersed X-ray analyses (SEM/EDX, Hitachi Co., Ltd., Japan/Kevex Co., Ltd., USA).

\subsection{Chemical stability test}

Both samples were calcined at $1273 \mathrm{~K}$ for $10 \mathrm{~h}$ in air, and pressed into pellets under a pressure of 350 $\mathrm{MPa}$. Pellets were sintered at $1573 \mathrm{~K}$ for $5 \mathrm{~h}$ in air, and their relative densities were above $93 \%$ of theoretical densities. The chemical stability test was carried out by placing the pellets in $\mathrm{H}_{2}+\mathrm{H}_{2} \mathrm{O}$ gas mixture $\left(p\left(\mathrm{H}_{2}\right): p\left(\mathrm{H}_{2} \mathrm{O}\right)=98: 2\right)$ at $1273 \mathrm{~K}$ for $627 \mathrm{~h}$. After this treatment, the surfaces of samples were investigated by XRD and SEM/EDX.

\section{Results}

\subsection{Investigation on chracteristics of calcined powders}

Intermediate compounds in Sample 1 were found by powder XRD as shown in Fig. 1. At $823 \mathrm{~K}$,
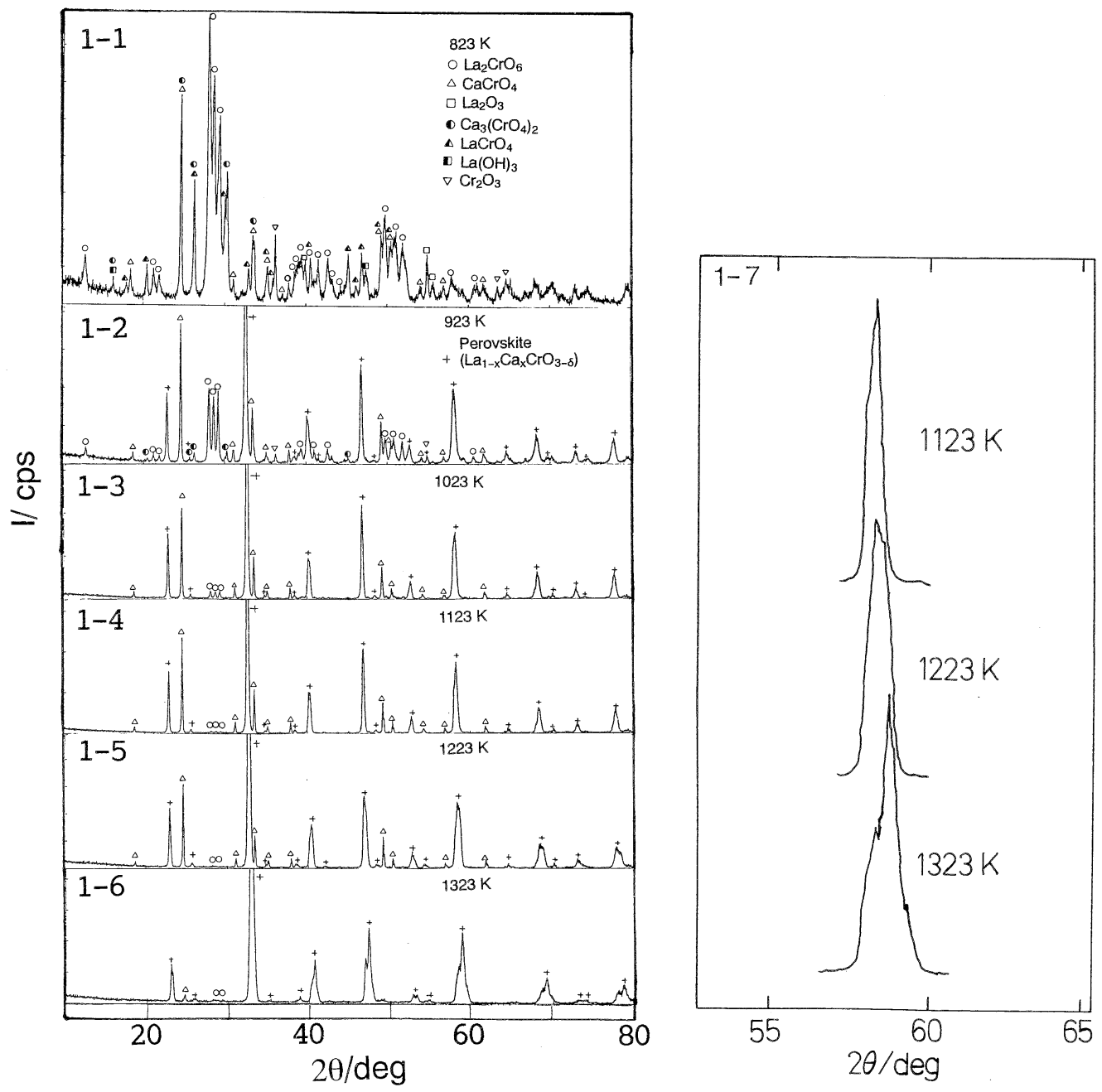

Fig. 1. XRD patterns of calcined powders in the preparation of Sample 1; calcined at $823 \mathrm{~K}(1-1)$, at $923 \mathrm{~K}(1-2)$, at 1023 K (1-3) at $1123 \mathrm{~K}(1-4)$, at $1223 \mathrm{~K}(1-5)$ and at $1323 \mathrm{~K}(1-6)$. Each perovskite peak splits in two at $1223 \mathrm{~K}$ and in three at 1323 K (1-7). 
$\mathrm{CaCrO}_{4}, \quad \mathrm{La}_{2} \mathrm{CrO}_{6} \quad \mathrm{LaCrO}_{4}$ and $\mathrm{Ca}_{3}\left(\mathrm{CrO}_{4}\right)_{2}$ were formed while a pretty amount of reactants such as $\mathrm{Cr}_{2} \mathrm{O}_{3}$ or $\mathrm{La}_{2} \mathrm{O}_{3}$ remained. At $923 \mathrm{~K}$, the perovskite phase $\left(\mathrm{La}_{1-x} \mathrm{Ca}_{x} \mathrm{CrO}_{3-\delta}\right)$ were formed, however, with increasing temperature above $923 \mathrm{~K}$, intensities of $\mathrm{La}_{2} \mathrm{CrO}_{6}$ and $\mathrm{Cr}_{2} \mathrm{O}_{3}$ decreased drastically, whereas $\mathrm{CaCrO}_{4}$ kept its intensity constant up to $1223 \mathrm{~K}$. Hence, it is thought that only $\mathrm{LaCrO}_{3}$ forms by the decomposition of $\mathrm{La}_{2} \mathrm{CrO}_{6}$ or by the reaction of $\mathrm{Cr}_{2} \mathrm{O}_{3}$ with $\mathrm{La}_{2} \mathrm{CrO}_{6}$ at $923 \mathrm{~K}$. With increasing temperature, calcium doped lanthanum chromite $\left(\mathrm{La}_{1-x}\right.$ $\mathrm{Ca}_{x} \mathrm{CrO}_{3-\delta}$ ) begins to form by the reaction of $\mathrm{LaCrO}_{3}$ with $\mathrm{CaCrO}_{4}$ and remaining $\mathrm{La}_{2} \mathrm{CrO}_{6}$.

This reaction scheme can be proved by the change of unit cell volume $(V)$ which was calculated from observed orthorhombic lattice parameters of the perovskite phase $\left(\mathrm{La}_{1-x} \mathrm{Ca}_{x} \mathrm{CrO}_{3-\delta}\right)$. The relation between the lattice parameters of $\mathrm{La}_{1-x} \mathrm{Ca}_{x} \mathrm{CrO}_{3-\delta}$ and calcium content $(x)$ has been already reported by Berjoan et al.,10) and confirmed by our experiments. ${ }^{6)}$ We obtained a linear relation of $V\left(\mathrm{~nm}^{3}\right)=$ $-0.02340 x+0.2352$ from our own data as shown in Fig. 2. The open circles in Fig. 3 show the unit cell volume of $\mathrm{La}_{1-x} \mathrm{Ca}_{x} \mathrm{CrO}_{3-\delta}$ in Sample 1. The calcium

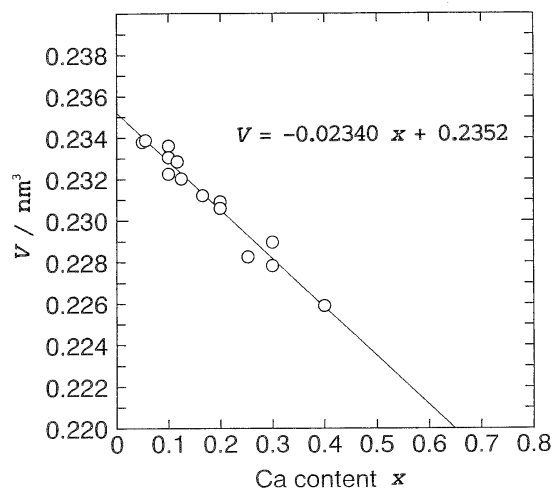

Fig. 2. Unit cell volume $(V)$ of $\mathrm{La}_{1-x} \mathrm{Ca}_{x} \mathrm{CrO}_{3-\delta}$ as a function of calcium content $(x)$ : Data were quoted from authors' previous work. ${ }^{6)}$

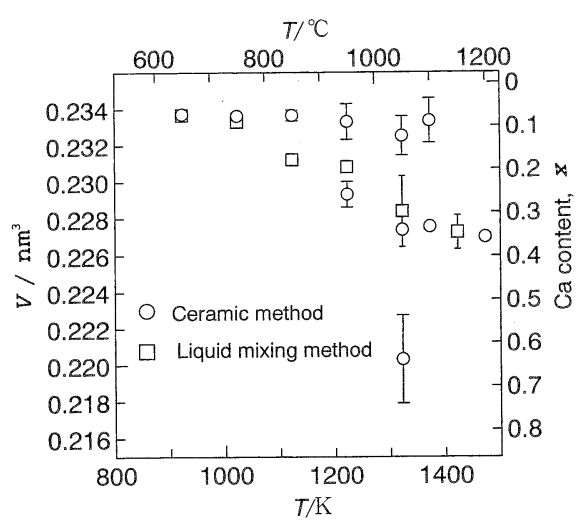

Fig. 3. Unit cell volumes $(V)$ of $\mathrm{La}_{1-x} \mathrm{Ca}_{x} \mathrm{CrO}_{3-\delta}$ calcined at different temperatures; $\bigcirc$ Sample 1; $\square$ Sample 2. Calcium content $(x)$ in $\mathrm{La}_{1-x} \mathrm{Ca}_{x} \mathrm{CrO}_{3-\delta}$ is estimated by using the equation, $V\left(\mathrm{~nm}^{3}\right)=-0.02340 x+0.2352$. contents $(x)$, which are evaluated from $V$ values, are shown on the right vertical axis. For Sample 1, $V$ is ca. $0.234 \mathrm{~nm}^{3}$ at the temperatures from 923 to 1123 $\mathrm{K}$, and this value is almost the same as that of nondoped $\mathrm{LaCrO}_{3}$. At $1223 \mathrm{~K}$, each XRD peak of the perovskite phase in Sample 1 splits in two (see Figs. 1-5 and 1-7). This doublet was observed on each perovskite peak regardless of its Miller index, which indicates that two kinds of perovskite phases formed. In such a case, each peak was deconvoluted and the cell volume was evaluated individually as two different perovskite phases. Furthermore, Figs. 1-6 and 1-7 show that each peak of $\mathrm{La}_{1-x} \mathrm{Ca}_{x} \mathrm{CrO}_{3-\delta}$ was observed as triplet, which indicates that three types of perovskite phases having different cell volumes $\left(0.232,0.227\right.$ and $\left.0.220 \mathrm{~nm}^{3}\right)$ may exist in Sample 1 at $1323 \mathrm{~K}$. Among these three types, the middle value of $0.227 \mathrm{~nm}^{3}$ corresponds to the cell volume of $\mathrm{La}_{0.7} \mathrm{Ca}_{0.3} \mathrm{CrO}_{3-\delta^{\prime}}$ and it is represented as the highest peak in each triplet. The value of 0.232 $\mathrm{nm}^{3}$ corresponds to $\mathrm{La}_{0.9} \mathrm{Ca}_{0.1} \mathrm{CrO}_{3-\delta}$ and $0.220 \mathrm{~nm}^{3}$ corresponds to the heavily doped perovskite phase, $\mathrm{La}_{0.4} \mathrm{Ca}_{0.6} \mathrm{CrO}_{3-\delta}$. This experimental fact indicates that the distribution of calcium content $(x)$ in the perovskite phase is large in Sample 1 when it is calcined at above $1223 \mathrm{~K}$ in air. A small amount of $\mathrm{CaCrO}_{4}$ and $\mathrm{La}_{2} \mathrm{CrO}_{6}$ remained as second phases at $1323 \mathrm{~K}$. The splits of $\mathrm{La}_{1-x} \mathrm{Ca}_{x} \mathrm{CrO}_{3-\delta}$ disappeared when the powder was calcined at $1473 \mathrm{~K}$ (Fig. 3).

In Sample 2, $\mathrm{LaCrO}_{4}$ becomes the main phase at $823 \mathrm{~K}$ (Fig. 4-1). Roy and $\mathrm{Nag}$ synthesized $\mathrm{LaCrO}_{4}$ by calcining $\mathrm{La}\left[\mathrm{Cr}{ }^{\mathrm{III}}\left(\mathrm{C}_{2} \mathrm{O}_{4}\right)_{3}\right] \cdot 9 \mathrm{H}_{2} \mathrm{O}$ (lanthanum trisoxalatochromate) at $893 \mathrm{~K} .{ }^{11)} \mathrm{We}$ observed that the $\mathrm{Cr}^{3+}$ component formed a soluble complex when the mixture of $(\mathrm{La}, \mathrm{Ca}, \mathrm{Cr})$ nitrate solutions was added to oxalic acid-ethanol solution. The soluble complex is thought to be $[\mathrm{Cr}$ in the formation of $\mathrm{LaCrO}_{4}$.

$\mathrm{LaCrO}_{4}$ is thought to be the precursor of $\mathrm{LaCrO}_{3}$, hence at $923 \mathrm{~K}, \mathrm{LaCrO}_{4}$ turns into $\mathrm{LaCrO}_{3}$ all at once (Fig. 4-2). No splits were observed in the perovskite phase $\left(\mathrm{La}_{1-x} \mathrm{Ca}_{x} \mathrm{CrO}_{3-\delta}\right)$ from 923 to $1323 \mathrm{~K}$. Since cell volumes gradually decreased with increasing the calcining temperature (Fig. 3), which implies that calcium doping in the perovskite lattice occurred smoothly in Sample 2. At $1323 \mathrm{~K}$, a small amount of $\mathrm{Ca}_{5}\left(\mathrm{CrO}_{4}\right)_{3} \mathrm{OH}$ was detected as well as $\mathrm{CaCrO}_{4}$ and $\mathrm{La}_{2} \mathrm{CrO}_{6}$ (Fig. 4-6).

Figure 5 shows that the SEM image of the powder of Sample 1 calcined at $1273 \mathrm{~K}$. White fine particles are (La, $\mathrm{Ca}) \mathrm{CrO}_{3-\delta^{\prime}}$ and EDX analyses showed that large grains contained only calcium and chromium, suggesting $\mathrm{CaCrO}_{4}$ or $\mathrm{Ca}_{m}\left(\mathrm{CrO}_{4}\right)_{n}$. Such large $\mathrm{Ca}_{m}$ $\left(\mathrm{CrO}_{4}\right)_{n}$ grains were also observed in Sample 2 calcined at $1273 \mathrm{~K}$ (Fig. 6).

3.2 Chemical stability test in reducing atmosphere

Figure 7 shows the XRD pattern of the surface of sintered pellet (Sample 1) before and after the chem- 


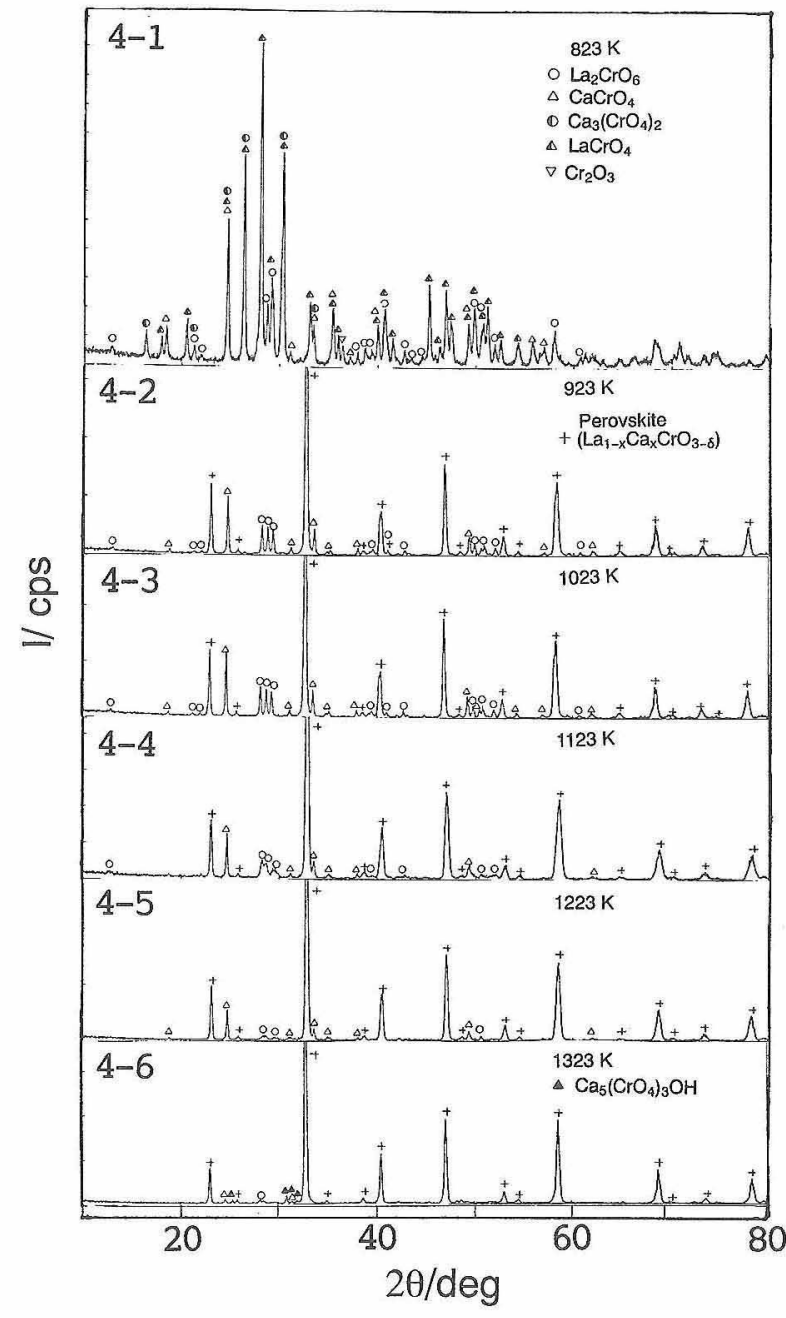

Fig. 4. XRD patterns of calcined powders in the preparation of Sample 2; calcined at $823 \mathrm{~K}(4-1)$, at $923 \mathrm{~K}(4-2)$, at $1023 \mathrm{~K}$ $(4-3)$ at $1123 \mathrm{~K}(4-4)$, at $1223 \mathrm{~K}(4-5)$ and at $1323 \mathrm{~K}(4-6)$.

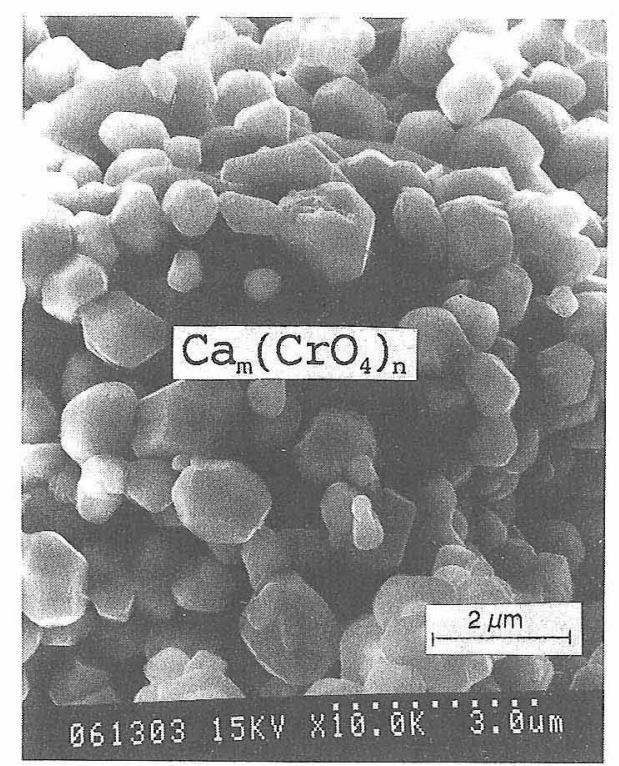

Fig. 5. SEM image of Sample 1 calcined at $1273 \mathrm{~K} . \mathrm{Ca}_{m}\left(\mathrm{CrO}_{4}\right)_{n}$ is observed as a large grain in the center of the image.

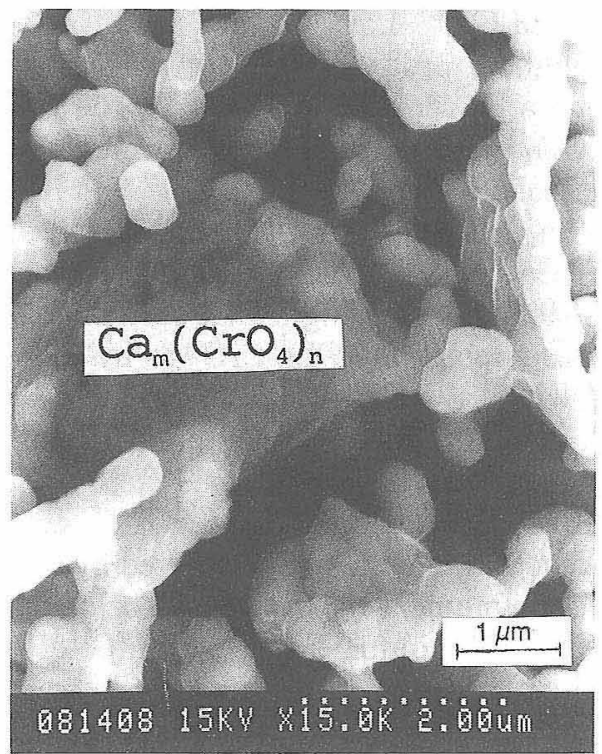

Fig. 6. SEM image of Sample 2 calcined at $1273 \mathrm{~K}^{-\mathrm{Ca}_{m}}\left(\mathrm{CrO}_{4}\right)_{n}$ is observed as a large grain in the center of the image.

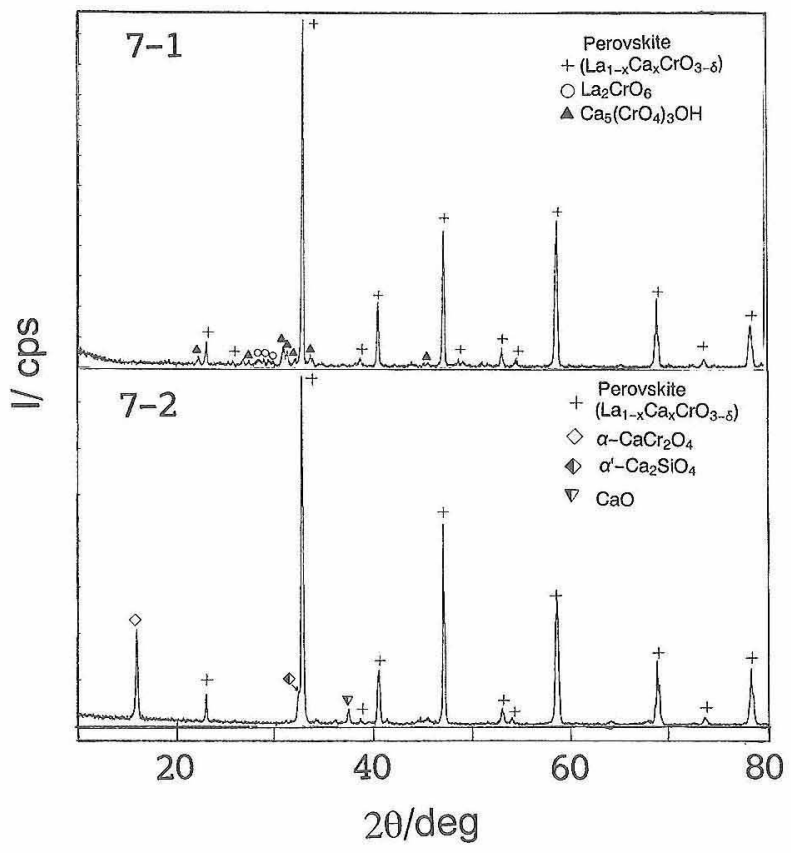

Fig. 7. XRD patterns on the surface of Sample 1 sintered at $1573 \mathrm{~K}$ for $5 \mathrm{~h}(7-1)$; after the exposure to $\mathrm{H}_{2}+\mathrm{H}_{2} \mathrm{O}$ at $1273 \mathrm{~K}$ for $627 \mathrm{~h}(7-2)$.

ical stability test. Before the test (Fig. 7-1), $\mathrm{Ca}_{5}$ $\left(\mathrm{CrO}_{4}\right)_{3} \mathrm{OH}$ and $\mathrm{La}_{2} \mathrm{CrO}_{6}$ were detected as well as the perovskite $\mathrm{La}_{1-x} \mathrm{Ca}_{x} \mathrm{CrO}_{3-\delta^{\prime}}$ which indicates that a pretty amount of second phases $\left(\mathrm{Ca}_{m}\left(\mathrm{CrO}_{4}\right)_{n}\right)$ remained on the surface. $\mathrm{CaO}, \alpha-\mathrm{CaCr}_{2} \mathrm{O}_{4}$ and $\alpha^{\prime}$ $\mathrm{Ca}_{2} \mathrm{SiO}_{4}$ were detected on the surface of the Sample 1 (Fig. 7-2) after the exposure to $\mathrm{H}_{2}+\mathrm{H}_{2} \mathrm{O}$ at 1273 $\mathrm{K}$ for $627 \mathrm{~h}$. Figure 8 shows the SEM image and the EDX profile of the surface of Sample 1 after the test. EDX analysis (Fig. 8-2) shows that only $\mathrm{Ca}, \mathrm{Cr}$ and Si components were detected on the surface, which 

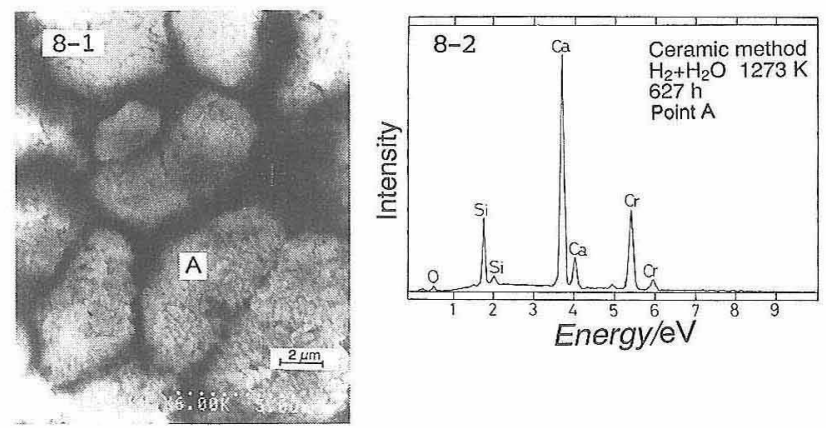

Fig. 8. SEM image (8-1) and EDX pattern (8-2) at point A on the surface of Sample 1 which was exposed to $\mathrm{H}_{2}+\mathrm{H}_{2} \mathrm{O}$ at $1273 \mathrm{~K}$ for $627 \mathrm{~h}$.

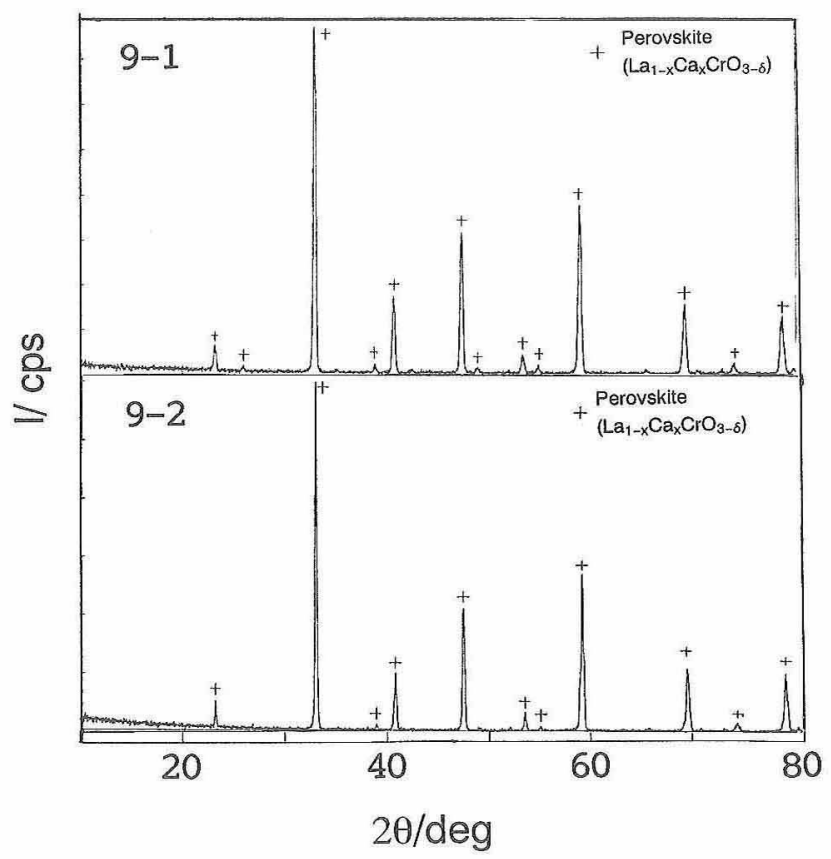

Fig. 9. XRD patterns on the surface of Sample 2 sintered at $1573 \mathrm{~K}$ for $5 \mathrm{~h}$ (9-1); after the exposure to $\mathrm{H}_{2}+\mathrm{H}_{2} \mathrm{O}$ at $1273 \mathrm{~K}$ for 627 h $(9-2)$.
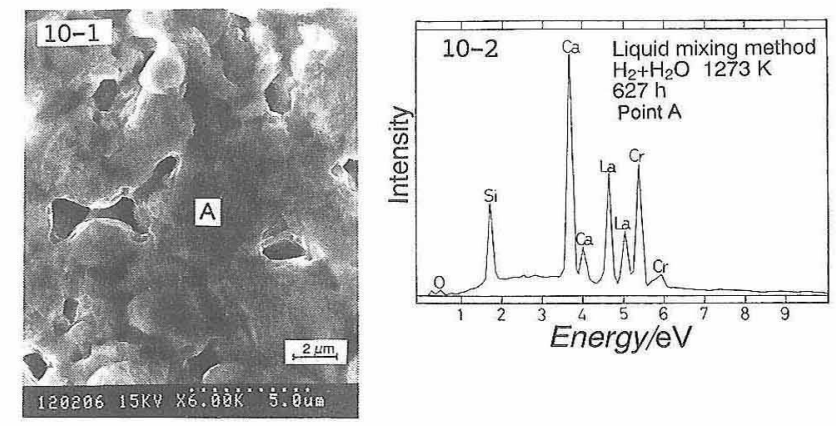

Fig. 10. SEM image (10-1) and EDX pattern (10-2) at point A on the surface of Sample 2 which was exposed to $\mathrm{H}_{2}+\mathrm{H}_{2} \mathrm{O}$ at $1273 \mathrm{~K}$ for $627 \mathrm{~h}$.

means that this sample was entirely covered by the mixture of $\mathrm{CaO}, \alpha-\mathrm{CaCr}_{2} \mathrm{O}_{4}$ and $\alpha^{\prime}-\mathrm{Ca}_{2} \mathrm{SiO}_{4} \cdot \mathrm{CaO}$ and $\alpha-\mathrm{CaCr}_{2} \mathrm{O}_{4}$ are thought to form as a result of decom- position of $\mathrm{Ca}_{5}\left(\mathrm{CrO}_{4}\right)_{3} \mathrm{OH}$. Silicon components are thought to come from crucibles and furnace elements, and result in the formation of $\alpha^{\prime}-\mathrm{Ca}_{2} \mathrm{SiO}_{4}$ by reacting with $\mathrm{Ca}_{5}\left(\mathrm{CrO}_{4}\right)_{3} \mathrm{OH}$.

The second phases were not observed in XRD on the Sample 2 prepared by the liquid mixing method (Fig. 9) before and after the test. However after the test, the SEM image of the surface (Fig. 10-1) shows that a small amount of second phase exists on $(\mathrm{La}, \mathrm{Ca}) \mathrm{CrO}_{3-\delta^{\prime}}$ and EDX analysis indicates that the amount of calcium and silicon components increased after the test (Fig. 10-2).

\section{Discussion}

The present results show that the preparation methods affect not only the compositions of intermediate compounds, but also the distribution of calcium content $(x)$ in the perovskite phase and the amount of second phases.

When samples were calcined at $1273 \mathrm{~K}, \mathrm{Ca}_{m}$ $\left(\mathrm{CrO}_{4}\right)_{n}$ including $\mathrm{CaCrO}_{4}$ were observed both in Sample 1 and Sample 2 by using SEM/EDX. The $\mathrm{La}_{1-x} \mathrm{Ca}_{x} \mathrm{CrO}_{3-\delta}$ grains which are adjacent to $\mathrm{Ca}_{m}$ $\left(\mathrm{CrO}_{4}\right)_{n}$ are thought to have an equilibrated calcium content $(x)$ which can be determined by $m / n$ ratio of $\mathrm{Ca}_{m}\left(\mathrm{CrO}_{4}\right)_{n}$ and temperatures, and the calcium content is much larger than $0.3 .^{8}$ Sample 1 has a perovskite phase having an very high calcium content $\left(\mathrm{La}_{0.4} \mathrm{Ca}_{0.6} \mathrm{CrO}_{3-\delta}\right)$ at $1323 \mathrm{~K}$, which indicates that a pretty amount of $\mathrm{La}_{1-x} \mathrm{Ca}_{x} \mathrm{CrO}_{3-\delta}$ may be in equilibrium with $\mathrm{CaCrO}_{4}$ or $\mathrm{Ca}_{m}\left(\mathrm{CrO}_{4}\right)_{n}$.

The XRD patterns show that only $\mathrm{CaCrO}_{4}$ and $\mathrm{La}_{2} \mathrm{CrO}_{6}$ are second phases in Sample 1 at $1323 \mathrm{~K}$, whereas the result of chemical equilibrium calculation reported by Yokokawa et al. shows that the nominal deficiency of chromium can be compensated by the $\mathrm{Ca}_{m}\left(\mathrm{CrO}_{4}\right)_{n}$ formation at that temperature. ${ }^{12)}$ However, when the reaction is retarded by some reasons, $\mathrm{CaCrO}_{4}$ can remain even at high temperature, which occurred in the preparation of Sample 1. Since Sample 1 was prepared by ceramic method, that is reasonable to assume that distribution of $\mathrm{Ca}_{m}$ $\left(\mathrm{CrO}_{4}\right)_{n}$ is much larger than that in Sample 2.

$\mathrm{Ca}_{m}\left(\mathrm{CrO}_{4}\right)_{n}$ form to compensate the nominal chromium deficiency, and they are necessary to densify the $\mathrm{La}_{1-x} \mathrm{Ca}_{x} \mathrm{CrO}_{3-\delta}$ at low temperatures in air. With elevating temperature above $1323 \mathrm{~K}, \mathrm{Ca}_{m}\left(\mathrm{CrO}_{4}\right)_{n}$ can dissolve into the perovskite, $\mathrm{La}_{1-x} \mathrm{Ca}_{x} \mathrm{CrO}_{3-\delta^{\prime}}$ and the exchanging of $\mathrm{Ca}^{2+}$ may also occur between the perovskite grains having different calcium content $(x)$ in Sample 1, which results in the disappearing of splits in XRD peaks. Simultaneously, remaining $\mathrm{Ca}_{m}\left(\mathrm{CrO}_{4}\right)_{n}$ begin to melt, and enhance the grain growth of the perovskite grains. The decrease of surface area depresses the rate of $\mathrm{Ca}_{m}\left(\mathrm{CrO}_{4}\right)_{n}$ dissolution to $\mathrm{La}_{1-x} \mathrm{Ca}_{x} \mathrm{CrO}_{3-\delta}$. Hence, a pretty amount of $\mathrm{Ca}_{m}\left(\mathrm{CrO}_{4}\right)_{n}$ may remain on the surfaces or at inner grain boundaries of Sample 1 even after the $(\mathrm{La}, \mathrm{Ca})$ $\mathrm{CrO}_{3-\delta}$ is sintered to near the theoretical density, 
which is shown in Fig. 7-1.

The appearance of $\mathrm{LaCrO}_{4}$ in Sample 2 is in satisfactorily good agreement with the results of chemical equilibrium calculations. ${ }^{12)}$ This suggests that during the powder preparation by the liquid mixing method, metal cations are well mixed to attain equilibrium states. The appearance of $\mathrm{Ca}_{5}\left(\mathrm{CrO}_{4}\right)_{3}$ $\mathrm{OH}$ at $1323 \mathrm{~K}$ is also in good agreement although some differences are in their compositions.

The present experimental results also indicate that chemical stability of sintered $(\mathrm{La}, \mathrm{Ca}) \mathrm{CrO}_{3-\delta}$ leads to the decomposition of $\mathrm{Ca}_{m}\left(\mathrm{CrO}_{4}\right)_{n}$. There is no possibility of the decomposition of $\mathrm{La}_{1-x} \mathrm{Ca}_{x}$ $\mathrm{CrO}_{3-\delta}$ since the activity of calcium is low in $\mathrm{La}_{1-x}$ $\mathrm{Ca}_{x} \mathrm{CrO}_{3-\delta}$. Hence, $\mathrm{CaO}$ and $\alpha-\mathrm{CaCr}_{2} \mathrm{O}_{4}$ are originated from second phases such as $\mathrm{CaCrO}_{4}$ or $\mathrm{Ca}_{m}$ $\left(\mathrm{CrO}_{4}\right)_{n}$ which are not stable in reducing atmosphere because of their high valence states of chromium. In Sample 1 , most of $\mathrm{CaO}$ and $\alpha-\mathrm{CaCr}_{2} \mathrm{O}_{4}$ are orginated from the $\mathrm{Ca}_{5}\left(\mathrm{CrO}_{4}\right)_{3} \mathrm{OH}$ which is detected on the surface by XRD before the test.

The present results of Sample 1 are similar to the results observed by Yasuda et a1.9) However, the amount of second phase in their report seems to be much more than that we observed on Sample 2. The amount of second phases $\left(\mathrm{Ca}_{m}\left(\mathrm{CrO}_{4}\right)_{n}\right)$ is thought to influence the extent of degradation of sintered $(\mathrm{La}$, Ca) $\mathrm{CrO}_{3-\delta}$ as a SOFC interconnect because the formation of $\mathrm{CaO}$ or $\alpha-\mathrm{CaCr}_{2} \mathrm{O}_{4}$ may prohibit the electrical contact between interconnects and other cell components. The present experiments imply that the amount of second phases in Sample 1 is much larger than in Sample 2, which is the reason why Sample 1 exhibited severer degradation. The result of Sample 2 shows that sintered $(\mathrm{La}, \mathrm{Ca}) \mathrm{CrO}_{3-\delta}$ has sufficient chemical stability in $\mathrm{H}_{2}+\mathrm{H}_{2} \mathrm{O}$ if the sample is prepared by the appropriate method to minimize the amounts of second phases.

The existence of silicon component plays an important role on the chemical stability of $(\mathrm{La}, \mathrm{Ca})$ $\mathrm{CrO}_{3-\delta}$. For example, if $\mathrm{SiO}_{2}$ exist with $\mathrm{CaCrO}_{4}$, the following reaction may occur:

$$
\begin{aligned}
4 \mathrm{CaCrO}_{4}+\mathrm{SiO}_{2} \rightarrow & 2 \mathrm{CaCr}_{2} \mathrm{O}_{4}+\mathrm{Ca}_{2} \mathrm{SiO}_{4} \\
& +3 \mathrm{O}_{2}(\mathrm{~g})
\end{aligned}
$$

If $\mathrm{SiO}_{2}$ is not contained in the powders, the following reaction will occur;

$$
4 \mathrm{CaCrO}_{4} \rightarrow 2 \mathrm{CaCr}_{2} \mathrm{O}_{4}+2 \mathrm{CaO}+3 \mathrm{O}_{2}(\mathrm{~g})
$$

According to the chemical equilibrium constant of each reaction, reaction (1) may proceed when $p\left(\mathrm{O}_{2}\right)$ $<2.73 \times 10^{-1}$ bar at $1273 \mathrm{~K}$, whereas reaction (2) proceeds when $p\left(\mathrm{O}_{2}\right)<5.92 \times 10^{-3}$ bar. That is, $\mathrm{SiO}_{2}$ enhances the decomposition of $\mathrm{CaCrO}_{4}$, which is due to the formation of stable $\alpha^{\prime}-\mathrm{Ca}_{2} \mathrm{SiO}_{4}$. The Gibbs energy change of $\alpha^{\prime}-\mathrm{Ca}_{2} \mathrm{SiO}_{4}$ formation from constituent oxides, $\mathrm{CaO}$ and $\mathrm{SiO}_{2}$, is $\Delta_{f} G^{\circ}=-121.848$ $\mathrm{kJ} \cdot \mathrm{mol}^{-1}$ at $1273 \mathrm{~K}$. (La, Ca) $\mathrm{CrO}_{3-\delta}$ can be contaminated by silicon components in laboratory experiments because the materials used for reaction vessel or furnace often contain $\mathrm{SiO}_{2}$. Furthermore, $\mathrm{SiO}_{2}$ and its related glassy materials are often used as adhesive agents for SOFC fabrication. Hence, the investigation on possible degradation of $(\mathrm{La}, \mathrm{Ca}) \mathrm{CrO}_{3-\delta}$ due to the use of $\mathrm{SiO}_{2}$-based glassy materials should be done especially at reducing atmosphere.

\section{Conclusion}

The present experimental results suggest that the ceramic method has some problems in the preparation of $(\mathrm{La}, \mathrm{Ca}) \mathrm{CrO}_{3-\delta}$. High temperature calcining was required to eliminate the distribution of calcium content $(x)$ in the perovskite phase $\left(\mathrm{La}_{1-x} \mathrm{Ca}_{x} \mathrm{CrO}_{3-\delta}\right)$. Such distribution caused a large amount of $\mathrm{Ca}_{m}$ $\left(\mathrm{CrO}_{4}\right)_{n}$, and resulted in chemical instability in reducing atmosphere. The liquid mixing method makes it possible to minimize the amount of second phase and good chemical stability. $\mathrm{Ca}_{m}\left(\mathrm{CrO}_{4}\right)_{n}$ as second phases remained on the surface of Sample 1 decomposed in reducing atmosphere at $1273 \mathrm{~K}$, which is enhanced by silicon components as impurities.

\section{References}

1) B. K. Flandermayer, J. T. Dusek, P. E. Blackburn, D. W. Dees, C. C. McPheeters and R. B. Poeppel, Abstracts of 1986 Fuel Cell Seminar, Tucson, Ariz., October, 1986. Courtesy Associates Inc., Washington, D. C. (1986) pp. 68-71.

2) W. Shafer and R. Schmidberger, "High Tech Ceramics", Ed. by P. Vincenzini, Elsevier Science Publishers B. V., Amsterdam (1987) pp. 1737-42.

3) C. Milliken, S. Elangovan and A. Khandkar, Proceedings of the International Symposium on Solid Oxide Fuel Cells, Nagoya, Japan, November 1989. Ed. by O. Yamamoto, M. Dokiya and H. Tagawa, Science House Co., Ltd., Tokyo (1990) pp. 50-57.

4) R. Koc and H. U. Anderson, J. Eur. Ceram. Soc., 9, 285-92 (1992).

5) V. L. Balkevich, A. V. Satanovskii, Yu. M. Mosin, V. E. Sotonikov and M. A. Andrianov, Steklo $i$ Karam., 12, 16-17 (1981).

6) N. Sakai, T. Kawada, H. Yokokawa, M. Dokiya and T. Iwata, J. Mater. Soc., 25, 4531-34 (1990).

7) N. Sakai, T. Kawada, H. Yokokawa, M. Dokiya and T. Iwata, Solid State Ionics, 40/41, 394-97 (1990).

8) N. Sakai, T. Kawada, H. Yokokawa and M. Dokiya, J. Am. Ceram. Soc., 76, 609-16 (1993).

9) I. Yasuda and T. Hikita, Abstracts of 1991 Fall Meeting of the Electrochemical Society of Japan (1991) p. 80.

10) R. Berjoan, C. Romand and J.-P. Coutures, High Temp. Sci., 13, 173-88 (1980).

11) A. Roy and K. Nag, J. Inorg. Chem., 40, 1501-05 (1978).

12) H. Yokokawa, N. Sakai, T. Kawada and M. Dokiya, Solid State Ionics, 52, 43-56 (1992). 